\title{
Monkey Business Practices on The Selling of "Janda Bolong" Plants in Indonesia: A Review of Islamic Economic Philosophy
}

\author{
Anis Wahdati1, Hendri Hermawan Adinugraha'2, Mansur Chadi Murshid ${ }^{3}$ \\ State Islamic Institute of Pekalongan ${ }^{1}$, \\ State Islamic Institute of Pekalongan', \\ State Islamic Institute of Pekalongan ${ }^{3}$ \\ dewimaharani922@gmail.com ${ }^{1}$
}

\begin{abstract}
The sale and purchase of the "Janda Bolong" plant which was busy in the midst of the Covid-19 pandemic at a very fantastic price, which was then suspected to contain monkey business practices. So this study aims to describe a review of the Islamic economic philosophy of monkey business practices in the "Janda Bolong" plants sale and purchase transaction. The research method used is a qualitative research method with the type of library research using a deductive approach. The results of this study indicate that the practice of buying and selling that occurs in the object of the plant "Janda Bolong" is a type of monkey business with objects that are not commonly practiced. The "Janda Bolong" plant sale and purchase transaction contains a fasid (damaged) contract, where the contract is in accordance with the Sharia but in the nature of the contract there is a problem. The price formation process that occurs in it is also unfair, so it is not in accordance with Islamic law. In Islamic economic philosophy, the practice of monkey business in buying and selling the "Janda Bolong" plant is not allowed. Because it denotes the essence of the creation of humans on earth, namely as a caliphate by processing the available resources in order to achieve happiness in this world and the hereafter.
\end{abstract}

Key words: Monkey business, Janda Bolong, and Islamic economic philosophy

\begin{abstract}
Abstrak
Jual beli tanaman "Janda Bolong" yang sedang ramai ditengah pandemic Covid19 dengan harga yang sangat fantastis, yang kemudian diduga mengandung praktik monkey business. Maka penelitian ini bertujuan untuk mendaskripsikan tinjauan filsafat ekonomi Islam terhadap praktik monkey business pada transaksi jual beli tanaman "Janda Bolong". Metode penelitian yang digunakan adalah metode penelitian kualitatif dengan jenis penelitian kepustakaan dengan menggunakan pendekatan deduktif. Hasil dari penelitian menunjukkan bahwa Praktik jual beli yang terjadi pada objek tanaman "Janda Bolong" termasuk jenis monkey business dengan objek yang tidak lazim diniagakan. Transaksi jual beli tanaman "Janda Bolong" mengandung akad yang fasid (rusak), dimana secara akad sesuai dengan syariat tetapi pada sifat akad terdapat suatu masalah. Proses pembentukan harga yang terjadi didalamnya juga tidak adil, sehingga tidak sesuai dengan syariat Islam. Secara filsafat ekonomi Islam, praktik monkey business pada jual beli tanaman "Janda Bolong" tidak diperbolehkan. Karena hal tersebut menayalahi hakikat diciptakannya manusia dibumi yaitu sebagai khilafah dengan
\end{abstract}


cara mengolah sumber daya yang tersedia guna mencapai kebahagiaan di dunia dan akhirat.

Kata kunci : Monkey business, Janda Bolong, dan filsafat ekonomi Islam

\section{INTRODUCTION}

Basically, Islamic law allows buying and selling transactions with the aim of obtaining profits to support his family or to be used as a means of worshiping Allah SWT by means of charity and others (Nuril Misbach et al., 2019). The values and norms of Islamic law regarding buying and selling transactions must be adhered to so that all transactions that are carried out get Ridha from Allah SWT (Mustikawati et al., 2019; Pujiyanti \& Wahdi, 2020).

If all activities on earth have one goal, namely as a means of worship and seeking Ridha Allah SWT, then social inequality will not occur (Ghafur, 2018). In Islamic economic philosophy, everything that is done by humans aims to achieve happiness in the world and the hereafter, including buying and selling transactions (Hanapi, 2020). In Islamic economic philosophy, buying and selling transactions are actually transactions of help, because the seller provides what the buyer needs, and vice versa, the buyer buys what is needed by using a medium of exchange, one of which is money (Sitepu, 2016). If the two parties, between the seller and the buyer, are not disadvantaged and mutually beneficial, then the transaction can be said to be valid or in accordance with the original goal of achieving the Ridha Allah so as to achieve happiness in both the world and the hereafter (Bhuiyan et al., 2020).

Along with the times, accompanied by technological advances, it is actually able to have an impact on the development of the diversity of buying and selling transactions which in the end also has the opportunity to cause new problems that do not have legal clarity (Novotny et al., 2021). Like the buying and selling of "Janda Bolong" plants which are busy in the midst of the Covid-19 pandemic.

The "Janda Bolong" or Monstera plant is not a plant originating from Indonesian soil (Cedeño-Fonseca, Hay, et al., 2020). Actually, the "Janda Bolong" plant comes from South America and Central America. The price is fantastic, in fact it is able to grab the attention of the Indonesian people who then flock to look for these plants (Rahman, 2018). The phenomenon that occurs in the "Janda Bolong" sale and purchase transaction has actually occurred in Indonesia several years ago, it's just that the object is different, namely the sale and purchase of love wave plants (anthurium), agate, arowana fish, louhan, love birds, and many more business opportunities excitement above that shocked the community where in the practice of buying and selling it is suspected that there are monkey business practices. 
Monkey Business Practices on The Selling of "Janda Bolong" Plants in Indonesia: A Review of Islamic Economic Philosophy

Monkey business is not a business of buying and selling monkeys, the connotation is only a metaphor or a term based on the behavior of monkeys when they get a lot of food (Sieber \& Kistler, 2014; Conly \& Johnston, 2008). The behavior of monkeys when they get a lot of food will immediately run away (Burton, 2016), this is then used as a metaphor in a business where when the main business actor has obtained many benefits for himself in various ways, even though this method is by deception or a way that is capable of harming other parties, then the perpetrator will run away or run away (Burton, 2019).

In fact, a monkey business is a long-term oriented business to take advantage of itself which then affects the losses of others, even though the goods used in these transactions are halal goods (Adinugraha et al., 2017; Rinda Rosmala, 2019). The provisional suspicion is that the monkey business practices that occur in the "Janda Bolong" plant are motivated by prices that have penetrated billions of rupiah amid the Covid-19 pandemic crisis (Lee \& Trimi, 2021).

For someone who has been crazy about the beauty of this "Janda Bolong" plant, the price is not a problem, whatever the seller has to offer can be sure to be bought (Mahacakri, 2020). There are three types of "Janda Bolong" which are the prima donna of plant lovers and have very high prices, including Monstera Andasonii, Monstera Abliqua, and Monstera Deliciosa (Nugroho et al., 2019). From this background, the researcher answered the above problems by focusing on researching the practice of monkey business on the sale and purchase of the "Janda Bolong" plant in terms of Islamic economic philosophy. Therefore, this study also describes a review of the Islamic economic philosophy of monkey business practices in the "Janda Bolong" plant sale and purchase transaction.

\section{METHOD}

This research is a qualitative research using library research (Library Research). Library Research is a series of activities related to methods of collecting library data, reading and taking notes and processing research materials. Library Research is a study that utilizes library sources to obtain research data (Danandjaja, 2014). In this study, researchers used a critical descriptive research method by relying on the theory and concepts used to be interpreted based on a review of the Islamic economic philosophy of monkey business practices in the "Janda Bolong" plant sale and purchase transaction, by emphasizing the power of sources analysis of relevant data.

The method used to process the data in this study is to carry out further analysis of the results of research organization based on theoretical principles and literature so as to be able to produce accurate conclusions regarding the review of Islamic economic philosophy on monkey business practices in the "Janda Bolong" plant sale and purchase transaction. 
Deductive research method is used in this research. This is because to get an overview of monkey business practice and Islamic law, which can then be drawn conclusions about the analysis of Islamic law on monkey business practices in "Janda Bolong" buying and selling.

\section{RESULTS AND DISCUSSION}

\section{Islamic Economic Philosophy: Theoretical Framework}

The word philosophy comes from Arabic philosophy which is derived from the Greek philosophia which is a compound word from the word philein which means love or philia which means love and the word sophia which means wisdom (Ridwan, 2016). Based on the meaning of each of these words, it can be concluded that philosophy means loving wisdom (Alvargonzález, 2020). In Arabic, doers or people who love wisdom are called philosophers, and if translated into Indonesian they are called philosophers. A person who thinks wisely and wisely and is able to behave with mature intellectual abilities by considering his moral values is a philosopher's actor (Stimpson \& Calvert, 2021).

Economic philosophy is the basic principle of a built economic system. This economic philosophy is the guide in economic activity (Dow, 2021). From economic philosophy derived instrumental values as a set of rules of the game an economic activity (Feige, 2019). Some of the main things covered in economic philosophy are the objectives of the economic activities of production, distribution, economic development and so on (Robinson et al., 2020). Islamic economic philosophy becomes the basic orientation of economics whose basic paradigm is relevant to logical, ethical and aesthetic values which are then applied in the economic behavior of society. The philosophy of Islamic economic law is based on the philosophy of God, man and nature (Hidayat, 2010) (Muheramtohadi, 2018).

The basic values of Islamic economics include three things (Sulistyowati, 2017). First, the concept of ownership which states that ownership in Islam is not absolute control over economic resources, but the ability to utilize them. Man's ownership of his property is limited by the limits of his life on earth. Ownership of natural resources relating to the livelihoods of the community belongs to the public and the control rests with the state. Second, the concept of balance between worldly and ukhrawi values and between individual interests and common interests, the balance between rights and obligations. Third, the value of justice, namely justice in the process of production and consumption, the process of distribution and fairness in the allocation of the results of economic activity by setting aside the obligation of assets in the form of paying zakat. These three basic values become the basic spirit for the instrumental values of Islamic economics (Ridwan, 2016). 
Monkey Business Practices on The Selling of "Janda Bolong" Plants in Indonesia: A Review of Islamic Economic Philosophy

In the context of the philosophy of science, based on its point of view, science can be divided into two, namely a positivistic view and a normative view (De Haro, 2020; Chirimuuta, 2020). Meanwhile, Islamic economics has two sides in question. On the one hand, Sharia economics displays distinctive characteristics as normative science, while on the other hand Sharia economics shows characteristics as empirical science (Ivlev et al., 2019).

As the mother of Sharia economics, Islamic law, when examined from the perspective of the philosophy of science (epistemology) (Nagatsu et al., 2020), can be done with two approaches, namely the philosophical approach and the historical empirical approach of Islamic law (M, 2012). Sharia philosophy includes: theoretical philosophy (al-hikmah al-nazariyyah), and practical philosophy (al-hikmah al-amaliyah) (Leaman, 2020). While empirically historically, there are three main pillars of Sharia science as pure science, namely the philosophy of Sharia science, methodology of Sharia science, and science of Sharia or science of fiqh, and one pillar of Sharia science as applied as-siyasah asy-syari'ah (Murtadho, 2015; Leaman, 2020).

\section{The Practice of Selling and Buying Plants "Janda Bolong"}

The "Janda Bolong" plant has the scientific name Monstera Adansonii. The "Janda Bolong" plant is also known as the Swiss cheese plant. Launching the United States Department of Agriculture Natural Resources Conservation Service, the scientific classification of this plant is (Soil Survey Staff, 2016):

a. Kingdom: Palntae

b. Sub Kingdom: Tracheobioata

c. Division: Magnoliophyta

d. Class: Liliopsida

e. Family: Araceae

f. Genus: Monstera Adans

Meanwhile, according to Gardens by The Bay, Monstera Adansonii has leaves with irregular oval-shaped holes and full-edged ornamental leaves. The Monstera Adansonii plant comes from Central America and South America. Monstera Adansonii is a vine suitable for trellis (Gomathi et al., 2014). If it is supported on a pole, the "Janda Bolong" will grow tall with bigger leaves. If used as an ornamental plant, this plant is usually about 1 meter high. However, if grown in the wild, the height of "Janda Bolong" can reach 2-4 meters.

Launching The Spruce, Monstera adansonii has relatives that are similar to the type of Monstera deliciosa. Both of them have a striking shape, namely leaves with holes. As a place to live, this plant is compatible with indirect sunlight, as it lives in the wild and grows in the shade of trees (Cedeño-Fonseca, Grayum, et al., 2020). The most suitable place is peat- 
based soil in potting holes that have large drainage holes. Peat is able to hold moisture in the soil without having to be flooded. To keep it growing, stick your finger into the soil to see how wet or dry it is. If it's almost dry, then water it and don't let "Janda Bolong" dry completely. "Janda Bolong" has about 41 species belonging to the genus Monstera, and all of them originate from Central and South America (Madison, 1977).

The era of the Covid-19 pandemic has an impact on increasing online buying and selling transactions (Nalini, 2021), including the sale and purchase of ornamental plants, including the "Janda Bolong" plant. It can be seen in various types of marketplaces that the price of "Janda Bolong" varies widely. Actually, there is nothing wrong with online transactions in terms of the law. Because there have been many studies that discuss the law of buying and selling online (Lubis, 2018). In this study, the discussion will focus on the transactions that are in it.

Philosophically, buying and selling activities have the value of worship. The sale and purchase transactions contained in it are required in accordance with the principle of sale and purchase which has been exemplified by the Prophet Muhammad. But the practice of monkey business proves that there are still people who put aside the goal of happiness in the hereafter (Khaerul Aqbar et al., 2020). One of them is in the sale and purchase transaction of this "Janda Bolong" plant. To find out whether the sale and purchase of the "Janda Bolong" plant is included in monkey business practice, there are several things that need to be analyzed, namely in terms of harmonious and legal terms and the price formation process contained therein.

At first glance, monkey business practice looks like ordinary real business, because the goods or objects that are traded are clear, the exchange between prices and objects of sale and purchase occurs in real terms, and the absoluteness of prices and goods is also real. In practice, there is no apparent reason that causes the transaction to be prohibited, such as the existence of usury, maisir, gharar and Ghabn. But if examined more deeply, monkey business activity is a long-term oriented business for self-profit.

In the practice of buying and selling the "Janda Bolong" plant in various marketplaces, there is a legal consent and qobul. This is evidenced by the price printed on the "Janda Bolong" plant image. When the buyer has made a payment through the marketplace, this shows that the buyer has agreed to the price offered by the seller. So legally buying and selling, the transaction is valid. But the price that is formed in it is unclear. Because the prices vary, there are several sellers who sell according to the number of leaves, there are sellers who sell according to the number of holes, there are sellers who sell by type, and there are still many unclear price formation ways. 
Monkey Business Practices on The Selling of "Janda Bolong" Plants in Indonesia: A Review of Islamic Economic Philosophy

There are "Janda Bolong" plants in one pot offered up to millions of rupiah, there are also buyers who barter with luxury cars, and many more. This clearly shows that there are related parties who carry out price hikes in order to take advantage of themselves in an unclear manner. The price that is formed is not in accordance with the existing demand function and supply function. Even though in Islam, the price formed in the buying and selling transaction process must be fair. Fair refers to the formation of a natural price, where the price formed is the result of the meeting of supply and demand points so that neither party feels disadvantaged. Because in Idlam it prohibits buying and selling by eating other people's property in vanity.

Although it seems unique and rare, the "Janda Bolong" plant can actually be found in various plantation areas (forests) or bushes. So it can be concluded that by contract, the practice of buying and selling the "Janda Bolong" plant is legal.

\section{Practice of Monkey business towards "Janda Bolong" Plant Sale and Purchase in Islamic Economic Philosophy Perspective}

Buying and selling based on Islamic law, sale and purchase is an agreement to exchange objects or goods that have a voluntary value between the two parties, one accepts the objects and the other party accepts them in accordance with the agreement or conditions that have been justified by Sharia and agreed upon (Nuril Misbach et al., 2019). What is meant by legal provisions is fulfilling requirements, rukun-rukun and other things that are related to buying and selling, then if the conditions and rukunyna are not fulfilled it means that it is not in accordance with the will of Sharia (Norman \& Aisyah, 2019). There are three pillars of buying and selling, namely the contract (Ijab Qabul), the people who have the contract (seller and buyer) and ma'qud alaih (object of the contract) (Muhammad Hatta S., 2016). In essence, buying and selling in Islam is allowed in accordance with the hadith which states that "law in mu'amalah is allowed unless there are arguments against it" (Adinugraha, 2017).

In language, buying and selling is an exchange between something and something. In Arabic it is often called al-bai' (Radzali et al., 2019). In Sharia, buying and selling is carried out with the aim of helping each other to meet the needs of life (Yusron Sholikhin \& Nurul Fitri Amijaya, 2019). In the process of life, humans have different professions according to their respective expertise. This results in diversity, so that humans are unable to live alone without the help of others. The permissibility of buying and selling contracts in Islam has been explicitly explained by the Al-Qur'an which is the guideline for human life, namely in Surah al-Baqarah verses 275, 282 and an-Nisa 'verse 29. 
Apart from being sourced from the Qur'an, the permissibility of buying and selling transactions has also been exemplified by the Prophet Muhammad SAW who was proven to be a trader and when the Prophet Muhammad was asked by his friend "what is the most noble livelihood?", Prophet Muhammad SAW also replied: someone who works with his hands and every mabrur (good) sale. "The purpose of mabrur buying and selling is buying and selling transactions that are avoided from fraudulent attempts to deceive and can harm other parties. Therefore, the philosophical basis of buying and selling is the statement of the Prophet Muhammad that "Buying and selling must be done on the basis of mutual willingness. Thus, buying and selling as a legal event will be considered valid / legitimate if the parties involved in the contract do not feel harmed, on the contrary they feel mutually beneficial" (Jamaludin, 2020).

The basic values that must be used as the basis when carrying out contract activities are the principle of not eating other people's assets in vain, the principle of mutual willingness, namely avoiding coercion that removes one's right to vote in carrying out business activities, the principle of not containing exploitation practices and mutually harming others persecuted, and the principle does not contain usury (Shobirin, 2016).

There are several things that must be understood before we want to find the concept of Islamic economic philosophy, one of which is that flexibility is needed due to the increasingly developing times, as well as the rapidly developing technology. In dealing with mu'amalah problems, the source that is most needed is ijtihad. Prophet Muhammad SAW also stated that $m u^{\prime}$ amalah is very dependent on human creativity and innovation.

In order to study the Islamic economic philosophy, it is important to first understand the philosophy of law to determine the location of the Islamic economic philosophy. Regarding this matter, Lili Rasjidi, an expert in the field of legal philosophy, after noting a number of definitions of legal philosophy concluded three things (Popov, 2019). First, that the philosophy of law is a branch of philosophy, namely ethical or moral philosophy. Second that the object of the discussion of legal philosophy is about the essence or essence of the law. Third, that the philosophy of law is a branch of science that further studies everything that cannot be answered by the branch of law. Thus, based on the layering theory of Islamic law and legal philosophy, Islamic economic philosophy should be different from the principles of Islamic economics; where the Islamic economic philosophy is the philosophical values or basic Islamic economics, which are the abstract norms and ideals of Islamic economics, while the principles are general values or principles; and that Islamic economic philosophy can be called ethics or economic morals (Nasution, 2002).

If the Islamic economic ontology is equated with the essence of the muamalat ontology, then the Islamic economic philosophy is the same as 
Monkey Business Practices on The Selling of "Janda Bolong" Plants in Indonesia: A Review of Islamic Economic Philosophy

the muamalat philosophy. Meanwhile, to be able to understand the philosophy of Islamic economics, one must first understand the principles of Islamic economics (R. M. Aziz, 2018).

In the philosophy of Islamic economic law, one form of contract is an exchange contract (Ahmad et al., 2012). The awareness that every human being is not able to fulfill his own needs perfectly is the basic philosophy of the law of the contract of exchange. Humans are social beings who must interact with each other in order to fulfill their material and spiritual needs (Azizah, 2016). Humans are interdependent creatures, which are creatures that are dependent on other humans. Therefore, the accounting contract becomes a necessity or even a necessity.

In Islamic law, any activity must be based on a noble or good motive and carried out based on the provisions of the Sharia so that it can be of worship value. One form of exchange agreement in Islamic economic law is a contract of sale and purchase (Dzubyan, 2019). The sale and purchase transactions that occur at the "Janda Bolong" plant object at a glance are valid, because the terms of sale and purchase are fulfilled, namely there are sellers and buyers, goods being traded, prices of goods being traded, and contracts. But when viewed from the point of view of the Islamic economic philosophy which states that all types of economic transactions have the goal of making the people prosperous based on the teachings of tawhid, then this is different. Because the pricing that is formed in such transactions is unnatural or deliberately designed to create high prices by certain parties for personal profit taking. This transaction is often called the monkey business.

Monkey business is a business strategy that is used to increase personal profits in various ways, one of which is fraud. At first glance, monkey business practice looks like ordinary real business, because the goods or objects that are traded are clear, the exchange between prices and objects of sale and purchase occurs in real terms, and the absoluteness of prices and goods is also real. In practice, there is no apparent reason that causes the transaction to be prohibited, such as the existence of usury, maisir, gharar and ghabn (Pardiansyah, 2017).

In fact, a monkey business is a long-term oriented business to take advantage of itself which then affects the losses of others, even though the goods used in these transactions are halal goods. The object of exchange in monkey business practice can consist of goods that are useful and clearly halal as well as goods that are not halal, even those that are not commonly traded.

The operating mode mechanism of monkey business in the "Janda Bolong" buying and selling scheme is more or less as follows:

a) The doer creates a product that seems valuable. One example is the "Janda Bolong" plant. 
b) The perpetrators seemed to buy all these products at a very high price, for example 5 million.

c) These actors must maintain a stable transaction until the goods are scarce in the market.

d) When the goods are on the verge of saturation, the actors will increase the price of these goods to be slightly higher, for example, the original price was 5 million to 5.5 million with the aim of spurring the public to hunt them down.

e) If it is felt that the general public cannot find the item, the actors will double the price, for example 10 million. However, the actors have eliminated the sales market.

f) When the item is truly scarce, the actors will sell the item to the general public by slightly lowering the price from 10 million to 8 million. So that the people who are hooked or the collectors will hunt down these items and consider them a luxury.

g) The actors will provide opportunities for the community to more easily obtain these items.

h) When the perpetrator has run out of goods, the perpetrators have reaped a lot of profit and the perpetrators have not chased the goods in the community.

i) People who have already bought in large quantities, who will then sell them again, already find it difficult to find buyers, because what will they be used for? Because the benefits of goods are not worth the very high price.

The practice of buying and selling that occurs in "Janda Bolong" plant objects is a type of monkey business with objects that are not normally demonstrated. Because the initiator has a long-term orientation in the form of creating an ondisi or dependency pattern, so that one day the party can play with a price for an item in the market. After it makes a profit, then it will leave the consumer. So that at that time, many parties suffered losses.

Those who practice monkey business are certainly sinners, because in the transaction there is an element of deliberation to harm the community. And of course this transaction is prohibited in Islamic law. However, to examine monkey business, one cannot simply study textual figh. But it must be seen from the contextual fiqh side, because it is related to the law of cause and effect (A. Aziz, 2020). In terms of contextual fiqh, in monkey business practice there is a movement towards actions that are prohibited by sharia because they have the potential to harm other parties.

The phenomenon that occurs in the "Janda Bolong" buying and selling transaction indicates fraud by certain parties in order to reap personal gain. This violates the basic values or principles in a contract. In addition, the buying and selling transactions that occur are different from what was taught by the Prophet, because the purpose of holding the sale 
Monkey Business Practices on The Selling of "Janda Bolong" Plants in Indonesia: A Review of Islamic Economic Philosophy

and purchase agreement should be to get benefits for both parties making the transaction. A strategy like monkey business is usually complemented by extraordinary business propaganda by means of exhibitions, seminars and large events at lucrative prices (Díez Martínez, 2012). So that many people are interested in playing in it. Even though at the event, the actors were capitalists who played to attract the public.

If it is analyzed based on the Islamic economic philosophy, that the sale and purchase of the "Janda Bolong" plant does not fulfill the basic values of life, that is, the seller does not apply the logical value in which the mature seller should be able to use his logic to distinguish between what is good and what is right. Apart from not fulfilling logical values, the "Janda Bolong" plant seller does not meet ethical values, where the sellers who trade buying and selling with "deceptive" elements do not have good ethics. Apart from these two values, the aesthetic value is also not fulfilled in the transaction, this is because the process of the sale and purchase transaction of the "Janda Bolong" plant contains an element of fraud, even though the products that are being traded contain no less aesthetic value. The failure to fulfill the values that are the basis of human life shows that the "Janda Bolong" buying and selling transaction does not fulfill the components of the Islamic economic philosophy, namely spirituality.

A component that is no less important in Islamic economic philosophy is intellectuality, where in this component, the involvement of logic is very much considered (Ghozali \& Sari, 2018). Although logic is used in everything, logic must be balanced with heart. In fact, the perpetrators who are the masterminds of the "Janda Bolong" plant sale and purchase transactions do not use their mind to understand and analyze the transactions that have been formed. This is evidenced by the impulse of reason to cheat.

When viewed from the aspect of justice, the sale and purchase transaction of "Janda Bolong" contains injustice, both distributive justice, commutative justice and legal justice. This is evidenced by the system or pattern formed by several parties, which is the cause of the high selling value of the "Janda Bolong" plant which is thought to be a monkey-busines practice so that it can harm other parties who are victims of this business game.

Unity in justice believes that life is not only in the world, but also in the hereafter, so that justice will not only be tangible and complete in the world, but until the hereafter justice will be given. So that the perpetrators who have injured a transaction, must be prepared to get justice in the world as well as in the hereafter. Given that the transactions that were formed during the sale and purchase of the "Janda Bolong" plant were legal, it does not mean that parties who deliberately have the intention of harming others are able to avoid justice from Allah SWT. 


\section{CONCLUSION}

This study concluded that the practice of buying and selling that occurred in the "Janda Bolong" plant object was a monkey business type with an object that was not commonly demonstrated. The "Janda Bolong" plant sale and purchase transaction contains a fasid contract, where the contract is in accordance with the Sharia but in the nature of the contract there is a problem. The price formation process that takes place in it is also unfair, so it is not in accordance with Islamic law. In Islamic economic philosophy, the practice of monkey business in buying and selling the "Janda Bolong" plant is not allowed. Because this denotes the essence of the creation of humans on earth, namely as a caliphate by processing available resources in order to achieve happiness in this world and the hereafter. The practice of buying and selling "Janda Bolong" plants can be detrimental to several parties, whereas in philosophy, everything done on earth, including buying and selling, must be intended to worship Allah SWT.

\section{BIBLIOGRAPHY}

Adinugraha, H. H. (2017). Penerapan Kaidah al-Ghunm bi al-Ghurm dalam Pembiayaan Mushārakah pada Perbankan Syariah. Economica: Jurnal Ekonomi Islam,

$8(1)$. https:/ / doi.org/10.21580/economica.2017.8.1.1827

Adinugraha, H. H., Isthika, W., \& Sartika, M. (2017). Persepsi Label Halal Bagi Remaja Sebagai Indikator Dalam Keputusan Pembelian Produk: As a Qualitative Research. Perisai : Islamic Banking and Finance Journal, 1(3), 180-195. https:// doi.org/10.21070/ perisai.v1i3.1365

Ahmad, A. A., Ahmad, S., Tahir, H. M., Shahimi, S., Mohamad, S., \& Zain, M. M. M. (2012). Islamic forward exchange contracts as a hedging mechanism: An analysis of wa cd principle. International Business Management, 6(1). https://doi.org/10.3923/ibm.2012.47.54

Alvargonzález, D. (2020). Philosophy: What for? Topicos (Mexico), 59. https:/ / doi.org/10.21555/TOP.V0I59.1146

Aziz, A. (2020). Akar Moderasi Beragama Di Pesantren (Studi Kasus di Ma'had Aly Sukorejo Situbondo dalam Terbentuknya Nilai-Nilai Moderasi Beragama). Ar-Risalah: Media Keislaman, Pendidikan Dan Hukum Islam, 18(1). https:/ / doi.org/10.29062/arrisalah.v18i1.348

Aziz, R. M. (2018). Hahslm Islamic Economics Methodology. ICoSEC (International Conference In Social, Economic and Culture).

Azizah, U. (2016). Marriage, Spirituality And Modern Society: Al-Ghazali's Thought. Teosofia, 5(1). https://doi.org/10.21580/tos.v5i1.1716

Bhuiyan, A. B., Ismail, A. G., Noor, A. H. M., Solaiman, M., \& Ali, M. J. (2020). The Islamic Economics Philosophy And Application Reality In The Existing Islamic Economic Activities In The World. International Journal of Shari'ah and Corporate Governance Research, 3(2). 
Monkey Business Practices on The Selling of "Janda Bolong" Plants in Indonesia: A Review of Islamic Economic Philosophy

https:/ / doi.org/10.46281/ijscgr.v3i2.850

Burton, A. (2016). Monkey business. In Frontiers in Ecology and the Environment (Vol. 14, Issue 5). https://doi.org/10.1002/fee.1291

Burton, A. (2019). Monkey business 2: hirsute hoodlums. In Frontiers in Ecology and the Environment (Vol. 17, Issue 6). https:/ / doi.org/10.1002/ fee.2078

Cedeño-Fonseca, M., Grayum, M. H., Croat, T. B., \& Blanco, M. A. (2020). Three new species of Monstera (Araceae: Monsteroideae: Monstereae) from the Cordillera de Talamanca in Costa Rica, threatened by the expansion of coffee plantations. Nordic Journal of Botany, 38(12). https://doi.org/10.1111/njb.02970

Cedeño-Fonseca, M., Hay, A., Grayum, M. H., \& Blanco, M. A. (2020). Two new endemic species of Monstera (Araceae: Monsteroideae: Monstereae) from Golfito in southern Costa Rica. Webbia, 75(1). https:/ / doi.org/10.36253/jopt-8091

Chirimuuta, M. (2020). Philosophy of science. In The Routledge Handbook of Philosophy of Colour. https:// doi.org/10.4324/9781351048521-5

Conly, J. M., \& Johnston, B. L. (2008). The infectious diseases consequences of monkey business. In Canadian Journal of Infectious Diseases and Medical Microbiology (Vol. 19, Issue 1). https:/ / doi.org/10.1155/2008/970372

Danandjaja, J. (2014). Metode Penelitian Kepustakaan. Antropologi Indonesia, 0(52). https:/ / doi.org/10.7454/ai.v0i52.3318

De Haro, S. (2020). Science and Philosophy: A Love-Hate Relationship. Foundations of Science, 25(2). https://doi.org/10.1007/s10699-01909619-2

Díez Martínez, D. (2012). Case study house program: Industry, propaganda and housing. Revista Proyecto, Progreso, Arquitectura, 6. https://doi.org/10.12795/ppa.2012.i6.03

Dow, S. (2021). Economic methodology, the philosophy of economics and the economy: another turn? Journal of Economic Methodology. https:/ / doi.org/10.1080/1350178X.2020.1868771

Dzubyan, D. M. (2019). Analisis Akad Ijarah Muntahiya Bittamlik (Imbt) Dalam Perspektif Hukum Islam Dan Hukum Positif Di Indonesia. Amwaluna: Jurnal Ekonomi Dan Keuangan Syariah, 3(2). https:/ / doi.org/10.29313/amwaluna.v3i2.4304

Feige, E. L. (2019). Underground Activity and Institutional Change: Productive, Protective and Predatory Behavior in Transition Economies. SSRN Electronic Journal. https:/ / doi.org/10.2139/ssrn.3400240

Ghafur, A. (2018). Etika Bisnis dalam Perspektif Islam. Iqtishodiyah: Jurnal Ekonomi Dan Bisnis Islam, 4(1). https://doi.org/10.36835/iqtishodiyah.v4i1.74 
Ghozali, M., \& Sari, T. T. (2018). Paradigma Filsafat Ekonomi Syariah Sebagai Suatu Solusi Kehidupan Manusia. DIKTUM: Jurnal Syariah Dan Hukum, 16(2). https:/ / doi.org/10.35905/diktum.v16i2.615

Gomathi, R., Karpagam, S., \& Prof, A. (2014). Larvicidal activity of Monstera adansonii plant extracts against Culex quinequefaciatus. $\sim 160 \sim$ Journal of Pharmacognosy and Phytochemistry, 3(3).

Hanapi, M. S. (2020). From jahiliyyah to Islamic worldview: in search of an Islamic economic philosophy. Imanensi: Jurnal Ekonomi, Manajemen, Dan Akuntansi Islam, 5(1). https:/ / doi.org/10.34202/imanensi.5.1.2020.1-16

Hidayat, M. (2010). An Introduction to The Sharia Economic: Pengantar Ekonomi Islam. An Introduction to The Sharia Economic.

Ivlev, V. Y., Ivlev, Y. V., \& Ivleva, M. L. (2019). Logical Methodology. RUDN Journal of Philosophy, 23(4). https:/ / doi.org/10.22363/2313-2302-201923-4-499-507

Jamaludin, J. (2020). Kontrak Jual Beli dalam Islam. MUAMALATUNA, 11(2). https:/ / doi.org/10.37035/mua.v11i2.3300

Khaerul Aqbar, Azwar Iskandar, \& Akhmad Hanafi Dain Yunta. (2020). Konsep al-Falah dalam Islam dan Implementasinya dalam Ekonomi. BUSTANUL FUQAHA: Jurnal Bidang Hukum Islam, 1(3). https:/ / doi.org/10.36701/bustanul.v1i3.206

Leaman, O. (2020). Islamic Philosophy: An Introduction. In Bloomsbury Encyclopedia of Philosophers Bibliographic Guides. https:/ / doi.org/10.5040/9781350994980-002

Lee, S. M., \& Trimi, S. (2021). Convergence innovation in the digital age and in the COVID-19 pandemic crisis. Journal of Business Research, 123. https://doi.org/10.1016/j.jbusres.2020.09.041

Lubis, M. I. (2018). Online Buying And Selling Transactions Under International Private Law. Journal of Private and Commercial Law, 2(1). https:/ / doi.org/10.15294/jpcl.v2i1.14499

M, S. (2012). Tipologi intelektual Muslim dalam bidang kajian fikih: studi terhadap karya-karya fikih dosen STAIN Bengkulu. Ijtihad: Jurnal Wacana Hukum Islam Dan Kemanusiaan, 12(2). https:/ / doi.org/10.18326/ijtihad.v12i2.237-258

Madison, M. (1977). A revision of Monstera (Araceae). Contributions from the Grey Herbarium, 207.

Mahacakri, I. G. A. C. (2020). Manajemen Usaha dan Penerapan Digital Marketing Tanaman Hias di Kota Mataram. AGROTEKSOS: Agronomi Teknologi Dan Sosial Ekonomi Pertanian, 30(1). https:/ / doi.org/10.29303/agroteksos.v30i1.549

Muhammad Hatta S. (2016). Akad Hybrid Pada Produk Qardh Beragun Emas. Jurisdictie: Jurnal Hukum Dan Syariah, 7(2). 
Monkey Business Practices on The Selling of "Janda Bolong" Plants in Indonesia: A Review of Islamic Economic Philosophy

Muheramtohadi, S. (2018). Perbandingan Antara Filsafat Ekonomi Islam Dan Barat. Jurnal STIE Semarang, 10(3). https:/ / doi.org/10.33747/stiesmg.v10i3.211

Murtadho, A. (2015). Corak pemikiran hukum islam dalam formulasi perbankan syari'ah: antara tekstualis dan substansialis. Economica: Jurnal Ekonomi Islam, 6(2). https:/ / doi.org/10.21580/economica.2015.6.2.790

Mustikawati, I. M., Handono, M., \& Zulaika, E. (2019). The Perspective of Islamic Law on a Mismatched Object in Online Sales and Purchases Transactions. Lentera Hukum, 6(2). https:/ / doi.org/10.19184/ejlh.v6i2.10839

Nagatsu, M., Davis, T., DesRoches, C. T., Koskinen, I., MacLeod, M., Stojanovic, M., \& Thorén, H. (2020). Philosophy of science for sustainability science. Sustainability Science, 15(6). https:/ / doi.org/10.1007/s11625-020-00832-8

Nalini, S. N. L. (2021). Dampak Dampak covid-19 terhadap Usaha MIkro, Kecil dan Menengah. Jesya (Jurnal Ekonomi \& Ekonomi Syariah), 4(1). https://doi.org/10.36778/jesya.v4i1.278

Nasution, K. (2002). Wilayah Kajian dan Filsafat Ekonomi Islam. Millah, II(2).

Norman, E., \& Aisyah, I. (2019). Bisnis Online Di Era Revolusi Industri 4.0 (Tinjauan Fiqih Muamalah). Al-Kharaj: Jurnal Ekonomi, Keuangan $\mathcal{E}$ Bisnis Syariah, 1(1). https:/ / doi.org/10.47467/alkharaj.v1i1.15

Novotny, I. P., Fuentes-Ponce, M. H., Lopez-Ridaura, S., Tittonell, P., \& Rossing, W. A. H. (2021). Longitudinal analysis of household types and livelihood trajectories in Oaxaca, Mexico. Journal of Rural Studies, 81. https:/ / doi.org/10.1016/j.jrurstud.2020.10.022

Nugroho, A., Sujani, S., \& Lukmana, A. H. (2019). Pemberdayaan Pengrajin Tanaman Hias Komersial. Prosiding Konferensi Nasional Pengabdian Kepada Masyarakat Dan Corporate Social Responsibility (PKM-CSR), 2. https:/ / doi.org/10.37695/pkmcsr.v2i0.416

Nuril Misbach, M., Muhammad Nafik Hadi, R., \& Prasetio, \& A. (2019). An Overview of Islamic Law Against Buy and Sell Sand of Kebon with a Liberation System in Mount Wurung, Mojokerto Regency. Cendekia: Jurnal Pendidikan Dan Pembelajaran, 13(1). https://doi.org/10.30957/cendekia.v13i1.55

Pardiansyah, E. (2017). Investasi dalam Perspektif Ekonomi Islam: Pendekatan Teoritis dan Empiris. Economica: Jurnal Ekonomi Islam, 8(2). https:/ / doi.org/10.21580/economica.2017.8.2.1920

Popov, E. A. (2019). Grounds for Conceptualizationof the Philosophy of Branches of Law. Russian Journal of Legal Studies, 6(2). https:/ / doi.org/10.17816/rjls18471 
Pujiyanti, S. D., \& Wahdi, A. (2020). Transaksi Bisnis Online dalam Perspektif Islam. SERAMBI: Jurnal Ekonomi Manajemen Dan Bisnis Islam, 2(2). https:/ / doi.org/10.36407/serambi.v2i2.173

Radzali, N. E., Muhammad Noor Habibi, N. A., Mohd Sabri, N. A., \& Ismail, S. A. (2019). Examining Contracts used in Islamic Trade Financing: Issues in Bai Al-Dayn and Murabahah. International Journal of Management and Applied Research, 6(4). https:/ / doi.org/10.18646/2056.64.19-028

Rahman, S. R. (2018). Variasi Morfologi Tumbuhan Famili Araceae di Wilayah Kabupaten Majene. Prosiding Seminar Nasional Pendidikan Biologi.

Ridwan, R. (2016). Konstruksi filosofis akad-akad ekonomi syariah. IJTIHAD Jurnal Wacana Hukum Islam Dan Kemanusiaan, 15(2). https://doi.org/10.18326/ijtihad.v15i2.257-274

Rinda Rosmala. (2019). FUNGSI UTILITAS BARANG HALAL. At Taajir: Jurnal Ekonomi, Bisnis Dan Keuangan Syariah, 1(1). https://doi.org/10.47902/attaajir.v1i1.24

Robinson, P., Lück, M., \& Smith, S. (2020). An introduction to tourism. Tourism, 3-31. https://doi.org/10.1079/9781789241488.0003

Shobirin, S. (2016). JUAL BELI DALAM PANDANGAN ISLAM. BISNIS : Jurnal Bisnis Dan Manajemen Islam, 3(2). https:/ / doi.org/10.21043/bisnis.v3i2.1494

Sieber, J. M., \& Kistler, R. (2014). Monkey Business. TEI 2014 - 8th International Conference on Tangible, Embedded and Embodied Interaction, Proceedings. https:// doi.org/10.1145/2540930.2555203

Sitepu, N. I. (2016). Prilaku Bisnis Muhammad SAW Sebagai Entrepreneur Dalam Filsafat Ekonomi Islam. Human Falah, 3(1).

Soil Survey Staff. (2016). Natural Resources Conservation Service, United States Department of Agriculture. Web Soil Survey.

Stimpson, B., \& Calvert, I. (2021). Qur'anic educational philosophy: Foundational principles of education in Islam's holiest text. Religions, 12(2). https://doi.org/10.3390/rel12020082

Sulistyowati, S. (2017). Rancang Bangun Dan Nilai Dasar Universal Ekonomi Islam. ISTITHMAR: Jurnal Pengembangan Ekonomi Islam, 1(2). https:/ / doi.org/10.30762/itr.v1i2.946

Yusron Sholikhin, M., \& Nurul Fitri Amijaya, R. (2019). E-Commerce Based on the Law of Buying and Selling in Islam. KnE Social Sciences, 3(13). https:/ / doi.org/10.18502/kss.v3i13.4290 